\title{
Valence Control of Technetium and Ruthenium for Anion Exchange Chromatographic Separation
}

\author{
Moo Yul Suh, ${ }^{\star}$ Chang Heon Lee, Kwang Soon Choi, Byoung Chul Song, Yeong Jae Park, and Won Ho Kim \\ Nuclear Chemistry Research Team, Korea Atomic Energv Research Institute, P.O. Box 105, Yusong. Daejeon 305-600, Korea \\ Received August 19, 2002
}

Key Words : Technetium. Ruthenium. Valence control, Anion exchange resin

\begin{abstract}
Analysis of ${ }^{19 y} \mathrm{Tc}$ in $\mathrm{LiCl}$ molten salt sample is required to calculate source terms to prepare for the recovery of metal uranium from uranium oxide spent nuclear fuel in $\mathrm{LiCl}$ molten salt medium by reduction with lithium metal. ${ }^{1}$ Technetium-99. which is formed by thernal neutron fission of ${ }^{235} \mathrm{U}$ and ${ }^{335} \mathrm{Pu}$, is a beta enitter with a long half-life of 2.1 $\times 10^{5} \mathrm{y}$. The content of ${ }^{9 y} \mathrm{Tc}$ in spent pressurized water reactor (PWR) fuel. after a cooling period of 10 years, is estimated at about $800 \mathrm{~g}$ per ton of uranium. ${ }^{2}$
\end{abstract}

To determine ${ }^{9 \%} \mathrm{Tc}$. using a liquid scintillation counter (LSC), the beta enitting nuclides, such as ${ }^{99} \mathrm{Mo}$ and ${ }^{1106} \mathrm{Ru}$. have to be removed from technetium solutions. While ${ }^{99} \mathrm{Mo}$ is negligible in the spent nuclear fuel with a long cooling period due to its relatively short half-life of 66 hours. the amount of ${ }^{1106} \mathrm{Ru}$ is 46 times as large as that of ${ }^{109} \mathrm{Tc}$, on the basis of beta activity, in the 10-year cooled spent nuclear fuels. ${ }^{2}$ Moreover, since the solubility of Tc-bearing alloys in $\mathrm{LiCl}$ molten salt is low, preconcentration and chemical separation of the technetium from $\mathrm{LiCl}$ molten salt samples are required for beta counting of ${ }^{9 \circ} \mathrm{TC}$.

As reported previously, any combination of ion exchange. solvent extraction, precipitation. and distillation has been used to remove the interfering beta activity nuclides. such as ${ }^{1100} \mathrm{Ru}$, from ${ }^{19} \mathrm{Tc}$ samples. ${ }^{3.5}$ Although anion exchange techniques have been widely used to separate technetium from ruthenium. they are frequently combined with other separation methods. Therefore. thermodynamic data, which are useful to eliminate ruthenium from technetium solely by anion exchange. are not conmonony available. This may be largely due to the fact that the anion exchanges were employed without proper valence control, specifically of ruthenium. ${ }^{3.6}$ Valence control of technetium and ruthenium is indispensable for the successful separation of the elements from each other by anion exchange techniques.

The present study was designed to establish an effective procedure to control the valences of technetium and ruthenium that is particularly suitable for the anion exchange separation of ${ }^{95} \mathrm{Tc}$ from $\mathrm{LiCl}$ molten salt samples from the uranium metalization process of spent nuclear fuel under development in the Korea Atomic Energy Research Institute. ${ }^{1}$

\section{Experimental Section}

Reagents and instruments. Analytical grade reagents and deionized water were used throughout this study.
$\mathrm{K}_{3} \mathrm{RuCl}_{6} .\left(\mathrm{NH}_{4}\right)_{2} \mathrm{RuCl}_{6 .} \mathrm{RuCl}_{3}$. sodium hypochlorite $(\mathrm{NaOCl})$ solution and $\mathrm{HCl}$ were purchased from Aldrich Chemical Co.. USA. The chlorine content of the $\mathrm{NaOCl}$ solution was determined by iodometric titration. ${ }^{10}$ Anion exchange AG 1 $\times 8(200-400$ mesh) in chloride form and cation exchange resin $A G 50 \mathrm{~W} \times 8(200-400$ mesh) in lydrogen form were used for the experiments. The aqueous solution of ammonium pertechnetate. of which ${ }^{99} \mathrm{Tc}$ purity was more than $99 \%$. was obtained from the An Eckert \& Ziegler Co. USA. Insta-gel XF (Packard) was used as a scintillator in liquid scintillation counting. The absorption spectra of solutions were measured with a Varian CARY5 UV-Vis-Nir spectrophotometer. using a $1.0 \mathrm{~cm}$ semi-micro quartz cell (Hellma). Determination of ruthenium was performed using a Jobin Yvon JY38 PLUS inductively coupled plasma atomic emission spectrophotometer (ICP-AES). Beta counting was made using a Packard 2500TR/AB, TRI-CARB liquid scintillation counter.

Valence control of Ru and Tc. A stock solution of 0.03 $\mathrm{M} \mathrm{K} \mathrm{RuCl}_{i}$ was prepared by dissolving an appropriate amount of solid $\mathrm{K}_{3} \mathrm{RuCl}_{\mathrm{i}}$ in $5.0 \mathrm{M} \mathrm{HCl}$. then diluted to 0.05 $\mathrm{M} \mathrm{HCl}$ solution with deionized water. An aliquot of $0.12 \mathrm{~N}$ $\mathrm{NaOCl}$, as much as 10 to 30 times more than the moles of ruthenium. was added to the diluted ruthenium solution followed by the addition of a few drops of $95 \%(\mathrm{~V} / \mathrm{V})$ ethanol. The absorption spectra of this solution were obtained with various time intervals in the range of 200-600 $\mathrm{nm}$. For $\left(\mathrm{NH}_{4}\right)_{2} \mathrm{RuCl}_{6}$ and $\mathrm{RuCl}_{3}$. the same experiments were performed.

A solution of Tc(IV) was prepared by adding concentrated hydrochloric acid to the aqueous solution of ammonium perteclunetate. The solution stood 40 days. with perteclunetate ion $\left(\mathrm{TcO}_{4}^{-}\right)$being converted to $\mathrm{TcCl}_{6}^{--}$. A portion of this solution was diluted to $0.022 \mathrm{mM} \mathrm{Tc}$ (IV) in $0.05 \mathrm{M} \mathrm{HCl}$ with deionized water. To the diluted Tc(IV) solution. an aliquot of $0.12 \mathrm{~N} \mathrm{NaOCl}$ solution and a few drops of $95 \%$ (V/V) ethanol were added in succession, and the absorption spectra of the solution were measured in the same manner as above.

Separation of ruthenium species. Cation exchange resin was pretreated by a common procedure and slurry-packed to 0.7 (i.d.) $\times 3.0 \mathrm{~cm}$ in a polyethylene columm. where the resin bed was held in place by glass wool plugs at the top and bottom. All anion exchange resin colunn of 0.7 (i.d.) $\times 3.0$ $\mathrm{cm}$ was prepared by the same procedure. The resin columns 
were preconditioned before use by passing $3 \mathrm{~mL}$ of $0.05 \mathrm{M}$ $\mathrm{HCl}$

Ten minutes after addition of $0.1 \mathrm{~mL}$ of $0.3 \mathrm{~N} \mathrm{NaOCl}$ solution to $5.0 \mathrm{~mL}$ of $3 \mathrm{mg} / \mathrm{L} \mathrm{Ru}$ (as a form of $\mathrm{K}_{3} \mathrm{RuCl}_{6}$ in $0.05 \mathrm{M} \mathrm{HCl}$ ) solution, one drop of $95 \%(\mathrm{~V} / \mathrm{V})$ ethanol was added to this combination. Fifteen minutes later, the solution was loaded on the $A G 50 \mathrm{~W} \times 8$ resin colunn. Nonadsorbed ruthenium on the resin was washed off with $5.0 \mathrm{~mL}$ of 0.05 $\mathrm{M} \mathrm{HCl}$, and adsorbed ruthenium was eluted with $10 \mathrm{~mL}$ of 5 $\mathrm{M} \mathrm{HCl}$. The effluent was collected fractionally. and the ruthenium concentration in each fraction was determined by ICP-AES. The same procedure was performed on the AG $\mathrm{I}$ $\times 8$ resin colunn.

Application of valence control technique. Two milliliters of $0.05 \mathrm{M} \mathrm{HCl}$ solution containing $30 \mu \mathrm{g} \mathrm{Ru}$ (as a form of $\mathrm{K}_{3} \mathrm{RuCl}_{6}$ ) and $3.4 \mathrm{nCi}{ }^{90} \mathrm{Tc}$ (as a form of $\mathrm{TcCl}_{6}{ }^{2-}$ ) were treated with $0.2 \mathrm{~mL}$ of $0.3 \mathrm{~N} \mathrm{NaOCl}$ and 3 drops of ethanol sequentially. and the solution was loaded on the AG $1 \times 8$ resin colunu [ 0.7 (i.d.) $\times 3.0 \mathrm{~cm}]$. which was preconditioned by passing $3 \mathrm{~mL}$ of $0.05 \mathrm{M} \mathrm{HCl}$. The column was then washed with $10 \mathrm{~mL}$ of $1.0 \mathrm{M} \mathrm{HNO}_{3}$ and $10 \mathrm{~mL}$ of $10 \mathrm{M}$ $\mathrm{HNO}_{3}$, in succession. The effluent was collected in fractions of $1.0 \mathrm{~mL}$, and the concentration of ruthenium and ${ }^{\text {by }} \mathrm{Tc}$ was measured by ICP-AES and LSC, respectively. The flow rate of the $A G l \times 8$ column was $0.3 \mathrm{~mL} / \mathrm{min}$.

A synthetic solution containing $0.05 \mathrm{M} \mathrm{HCl} .17 \mathrm{nCi}{ }^{99} \mathrm{Tc}$. $3.0 \mu \mathrm{g} \mathrm{Ru}$ and $100 \mathrm{mg} \mathrm{LiCl}$ was treated with $0.05 \mathrm{~mL}$ of 0.3 $\mathrm{N} \mathrm{NaOCl}$ followed by the addition of one drop of ethanol. The resulting solution was diluted to $10 \mathrm{~mL}$ with $0.05 \mathrm{M}$ $\mathrm{HCl}$. A $0.5 \mathrm{~mL}$ aliquot of this solution was loaded on the $\mathrm{AG}$ $1 \times 8$ resin column [0.7(i.d.) $\times 3.0 \mathrm{~cm}]$. After washing the column with $10 \mathrm{~mL}$ of $1.0 \mathrm{M} \mathrm{HNO}_{3}$, technetium was eluted with $10 \mathrm{~mL}$ of $10 \mathrm{M} \mathrm{HNO}_{3}$. A milliliter portion of $10 \mathrm{M}$ $\mathrm{HNO}_{3}$ effluent was taken and mixed with $14 \mathrm{~mL}$ of scintillation liquid followed by LSC of ${ }^{99} \mathrm{Tc}$ for 50 minutes. Experiments for the $A G \mathrm{I} \times 8$ resin column were performed three times.

\section{Results and Discussion}

Valence control of Ru and Tc. Technetium and ruthenium produced from the fission of uranium have been known to exist as a form of alloy in spent PWR nuclear fuels. ${ }^{11}$ When the uranium oxide powder from spent nuclear fuels is fed into $\mathrm{LiCl}$ molten salt at $650^{\circ} \mathrm{C}$. the alloy is expected to dissolve. at least in part in the molten salt and to be converted to the chloride forms. When these chlorides are dissolved in concentrated hydrochloric acid. various chlorocomplexes of the elements are formed in the solution. Thus. the ruthenium chlorides in different oxidation states of ruthenium. such as $\mathrm{K}_{j} \mathrm{RuCl}_{6}$. $\left(\mathrm{NH}_{4}\right) \mathrm{RuCl}_{6}$ and $\mathrm{RuCl}_{3}$, were selected in this study: Reports indicate that the average oxidation state of $\mathrm{RuCl}_{3}$ is closer to $\mathrm{Ru}(\mathrm{IV})$ than $\mathrm{Ru}(\mathrm{III}){ }^{12}$ It was also reported that no ionic chlorine is found in freshly prepared aqueous solutions of solid $\mathrm{RuCl}_{3}{ }^{13}$

Figure 1 summarizes the absorption spectra of ruthenium species $\left[\mathrm{K}_{3} \mathrm{RuCl}_{6} .\left(\mathrm{NH}_{4}\right)=\mathrm{RuCl}_{6}\right.$ and $\left.\mathrm{RuCl}_{3}\right]$ present in the

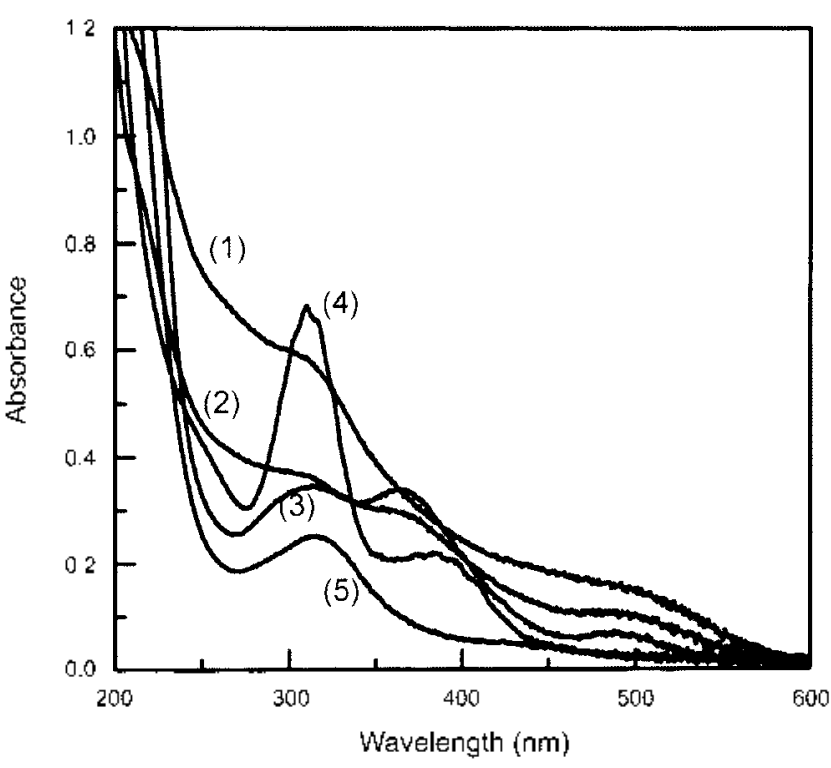

Figure 1. Absorption spectra of Ru-chlorocomplexes and $\mathrm{RuO}_{4}$ in $0.05 \mathrm{M} \mathrm{HCl}^{\prime}$ (1) $0.3 \mathrm{mM}\left(\mathrm{NH}_{4}\right)_{2} \mathrm{RuCl}_{0_{3}}(2) 0.3 \mathrm{mM} \mathrm{RuCl}_{3}$, (3) 0.3 $\mathrm{mM} \mathrm{K}_{3} \mathrm{RuCl}_{i,}$ (4) $0.3 \mathrm{mM} \mathrm{RuO},(5) 0.3 \mathrm{mM} \mathrm{Ru(III)}$ (a mixture of neurtal and cationic chlorocomplexes).

initial solutions of $0.05 \mathrm{M} \mathrm{HCl}$, as well as the absorption spectrum of the $\mathrm{K}_{3} \mathrm{RuCl}_{6}$ solution in $0.05 \mathrm{M} \mathrm{HCl}$ measured 5 minutes after the addition of $\mathrm{NaOCl}$. As might be expected. the absorption spectrum after the addition of $\mathrm{NaOCl}$ to the $\mathrm{K}_{3} \mathrm{RuCl}_{6}$ solution is much like that of ruthenium tetroxide $\left(\mathrm{RuO}_{4}\right)$, as reported in the literature. ${ }^{12}$ We observed no additional increase in the intensity of the $310 \mathrm{~nm}$ absorption band of $\mathrm{RuO}_{4}$ after the $\mathrm{NaOCl}$-treated $\mathrm{K}_{3} \mathrm{RuCl}_{6}$ solution stood 5 minutes. concluding that the ruthenium in a low valence state was instantaneously oxidized to $\mathrm{RuO}_{4}$ under this experimental condition. In the cases of $\left(\mathrm{NH}_{4}\right)_{2} \mathrm{RuCl}_{6}$ and $\mathrm{RuCl}_{3}$ solutions treated with $\mathrm{NaOCl}$ as described above, their absorption spectra were nearly identical to that of the $\mathrm{NaOCl}$-treated $\mathrm{K}_{3} \mathrm{RuCl}_{6}$ solution. These results led us to conclude that the ruthenium present as various chlorocomplexes of Ru(III) and $\mathrm{Ru}(\mathrm{IV})$ in $0.05 \mathrm{M} \mathrm{HCl}$ solutions was instantaneously oxidized to $\mathrm{RuO}_{4}$ by $\mathrm{NaOCl}$.

A small amount of ethanol was added to the nuthenium solution treated with $\mathrm{NaOCl}$ in an attempt to convert $\mathrm{RuO}_{4}$ to neutral or cationic cllorocomplexes of nuthenium. The change in the absorption spectrum of $\mathrm{RuO}_{4}$ due to the addition of ethanol to the $\mathrm{NaOCl}$-treated $\mathrm{K}_{3} \mathrm{RuCl}_{6}$ solution can be seen in (5) of Figure 1. Based on the suggestion by Cady and Connick. ${ }^{13}$ the broad absorption spectrum with a maximum at $315 \mathrm{~nm}$ can be attributed to the formation of $\mathrm{RuCl}_{2}, \mathrm{RuCl}_{2}^{+}$. and $\mathrm{RuCl}^{2+}$ from the reduction of $\mathrm{RuO}_{4}$ by ethanol. By employing $\mathrm{NaOCl}$ and ethanol in sequence. ruthenium can be rapidly and completely adjusted to the cationic and neutral species. which are not adsorbed on anion exchange resins.

To separate teclnetium from the interfering elements in LSC by anion exchange chromatography the interfering elements should be converted to the species that are not adsorbed or weakly adsorbed on the resin. while technetium 
is converted to the strongly adsorbed $\mathrm{TcO}_{4}^{-}$. It was necessary to confirm that the valence control procedure for ruthenium would also be effective in the oxidation of $\mathrm{TcCl}_{6}{ }^{-1}$ to $\mathrm{TcO}_{4}{ }^{-}$. Absorption spectrophotometric observations of the oxidation of $\mathrm{TcCl}_{6}{ }^{-}$by $\mathrm{NaOCl}$ in $0.05 \mathrm{M} \mathrm{HCl}$ revealed that $\mathrm{TcO}_{4}^{-}$was produced as an oxidation product at $245 \mathrm{~lm}$ and $290 \mathrm{~lm}$ in agreement with the literature. ${ }^{14}$ The oxidation reaction was completed within 5 minutes. We also found that the addition of ethanol to the $0.05 \mathrm{M} \mathrm{HCl}$ solution did not affect the stability of $\mathrm{TcO}_{4}^{-}$.

Identification of ruthenium species. To understand the behavior of ruthenium on anion exchange resin column. it is necessary to know the distribution and properties of individual species of ruthenium. Ion exchange methods cannot only be applied to the separation of ions. but can also provide information relevant to the properties of complexes formed between ion and ligand. To identify the species of ruthenium chlorocomplexes formed when treating ruthenium solution with $\mathrm{NaOCl}$ and ethanol in sequence. the species were isolated by cation and anion exchange techniques. When the treated solution was loaded on $\mathrm{AG} 50 \mathrm{~W} \times 8$ cation exchange column. about $70 \%$ of the ruthenium was found to be adsorbed by the resin from $0.05 \mathrm{M} \mathrm{HCl}$ solution, which could be eluted by $5.0 \mathrm{M} \mathrm{HCl}$. whereas the rest of the ruthenium was not adsorbed and thus easily washed off by $0.05 \mathrm{M} \mathrm{HCl}$ solution. This means that $70 \%$ of the ruthenium in the treated solution was present as a cationic species and $30 \%$ as the neutral and/or anionic species. In case of $\mathrm{AG} 1 \times$ 8 anion exchange resin. all ruthenium species in the treated solution were not adsorbed from $0.05 \mathrm{M} \mathrm{HCl}$ solution. which indicates that no anionic species of ruthenium was present in the solution treated with $\mathrm{NaOCl}$ and ethanol. These results support the conclusion from the absorption spectrophotometric observations that ruthenium in $0.05 \mathrm{M}$ $\mathrm{HCl}$ solution was converted to the neutral species $\mathrm{RuCl}_{3}$ and the cationic species, such as $\mathrm{RuCl}_{2}^{-}$and $\mathrm{RuCl}^{\hat{+}}$. It can also be concluded that the valence-controlled ruthenium species remained virtually unchanged on the resin column from the fact that the absorption spectra of the treated solution were identical with those of the effluent from $\mathrm{AG} 1 \times 8$ resin column.

Effectiveness of valence control. When ruthenium in $0.05 \mathrm{M} \mathrm{HCl}$ solution treated with only $\mathrm{NaOCl}$ was applied on $\mathrm{AG} 1 \times 8$ resin column. we observed that the color of the upper part of the resin bed changed from pale white to black. The black precipitation on the resin bed remained intact during washing stages with $1.0 \mathrm{M} \mathrm{HNO}_{3}$ and $10 \mathrm{M} \mathrm{HNO}_{3}$ solution. We found that most of the $\mathrm{RuO}_{4}$, a strong oxidant. was reduced to ruthenium hydroxides on the column by the ion exchange resin. This indicates that single use of $\mathrm{NaOCl}$ is not suitable for the valence control of nuthenium and technetium in anion exchange resin.

On treating the ruthenium in $0.05 \mathrm{M} \mathrm{HCl}$ solution with $\mathrm{NaOCl}$ and ethanol in sequence. neutral and cationic chlorocomplexes of ruthenium were formed which were not adsorbed on anion exchange resins. On the other hand, we found that. under the same condition. technetium was controlled to $\mathrm{TcO}_{4}^{-}$. which was strongly adsorbed on anion

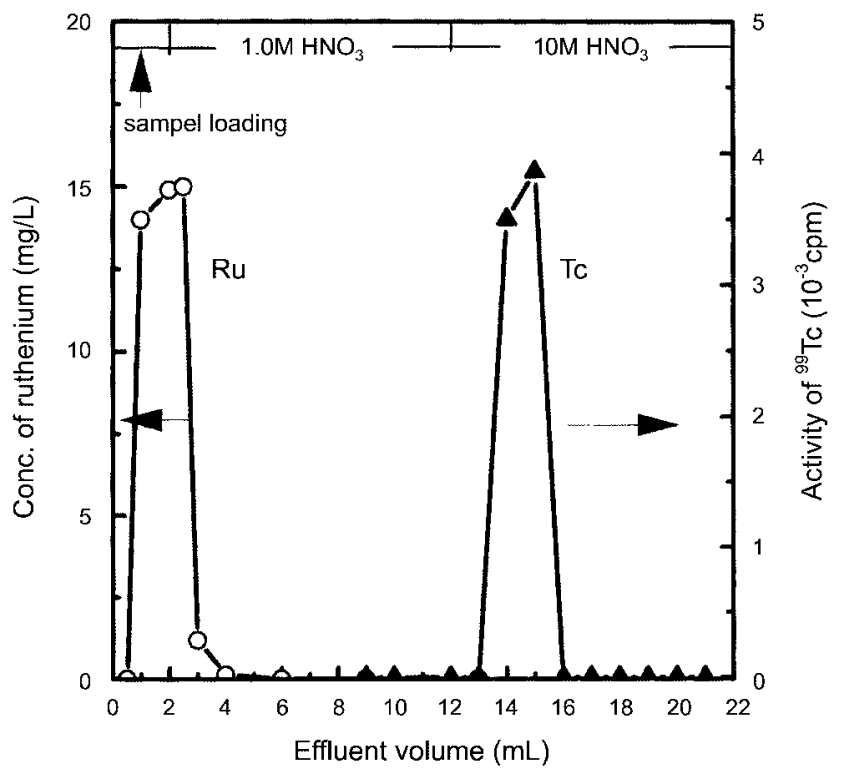

Figure 2. Separation of technetium from ruthenium on anion exchange resin; bed: 0.7 (i.d. $) \times 3.0 \mathrm{~cm}$, resirl: $A G 1 \times 8(200-400$ meshi, loaded amounts: $30 \mu \mathrm{g} \mathrm{Ru}$ and $3.4 \mathrm{nCi}{ }^{\circ 9} \mathrm{Tc}$ in $2.0 \mathrm{~mL}$ of $0.05 \mathrm{M} \mathrm{HCl}$, wash solution: $10 \mathrm{~mL}$ of $1.0 \mathrm{M} \mathrm{HNO}_{3}$, ellent: $10 \mathrm{~mL}$ of $10 \mathrm{M} \mathrm{HNO}_{3}$

exchange resins. This valence control was evaluated in terms of the effectiveness of the anion exchange procedure for the separation of teclunetium from ruthenium. Figure 2 shows a typical chromatogram obtained from $\mathrm{AG} I \times 8$ resin column operation with the $\mathrm{NaOCl}$-ethanol treated $0.05 \mathrm{M} \mathrm{HCl}$ solution containing ruthenium and ${ }^{9 \%} \mathrm{Tc}$ (as a form of $\mathrm{TcCl}_{6}{ }^{2-}$ ). Ruthenium was washed off the column with $1.0 \mathrm{M} \mathrm{HNO}_{3}$ solution, and then with $10 \mathrm{M} \mathrm{HNO}_{3}$ to obtain the technetium portion. As the ruthenium was not adsorbed. it was substantially passed through the column until the first $1 \mathrm{~mL}$ portion of $1.0 \mathrm{M} \mathrm{HNO}_{3}$, and teclunetium was completely eluted by less than $5 \mathrm{~mL}$ of $10 \mathrm{M} \mathrm{HNO}_{3}$ solution. Thus. 10 $\mathrm{mL}$ of $10 \mathrm{M} \mathrm{HNO}_{3}$ was sufficient to recover completely the technetium from the column. In addition. no technetium was found in the $10 \mathrm{~mL}$ effluent of $1.0 \mathrm{M} \mathrm{HNO}_{3}$. Moreover. ruthenium was not found in the teclnetium eluate by ICPAES. which confirms that ruthenium was completely removed from the resin column by the $1.0 \mathrm{M} \mathrm{HNO}_{3}$ washing step. This result indicates that separation of teclnetium from ruthenium can be achieved by combining the valence control technique with the anion exchange teclnique without the aid of other separation methods.

To examine the recovery of technetium and the reliability of the proposed procedure. three replicate experiments were performed with $A G 1 \times 8$ resin columuns on the synthetic solution containing ${ }^{99} \mathrm{Tc}$ and nuthenium. Lithium chloride medium solution has to be considered in this study. since this procedure is to be used for samples from $\mathrm{LiCl}$ molten salt process of uranium metal production. It was found that technetium recovery from $\mathrm{AG} 1 \times 8$ was $100.6 \%$ with a relative standard deviation of $2.3 \%$. This result shows that complete recovery of technetium on $\mathrm{AG} 1 \times 8$ columns can be achieved using the valence control procedure. 
Acknowledgment. This work was done under the Nuclear Research \& Development Progran by the Ministry of Science and Technology.

\section{References}

1. Seo. C. S.: Hur. J. M.: Lee. W. K.: Hong. S. S.: Kang. D. S.: Park. $\mathrm{S}$. W. A Situty on the Redtaction of Lrantum Oride to lrantum Metal in LiCl Molten Salr in Proceedings of the KNS-KARP Joint Spring Meeting: Gwangju. Korea. May 2002.

2. Ro, S. K. Park I. M: Min. D. K.: Choi B. I.: Sin H. S. KAERI: PIED note-001 87. 1987

3. Riley. J. P.: Siddiqui. S. A. Anal Chim Acta 1982. 139. 167.

4. Chen. Q.: Dahlgaard. H.: Hansen. H. J. M.: Aarkrog. A. Anal. Chim. Acta 1990, 228, 163.

5. East I. B. W. Radioact \& Radiochent 1994, 5, 20.
6. Butterworth, J. C.: Livens. F. R:; Makinson. P. R. Sci. Total Eniron. 1995.173:17+. 293.

7. Golchert. N. W.: Sedlet. J. Anal Chent 1969. \$1. 669

8. Chen. Q.: Aarkrog. A.: Dahlgaard. H.: Nielsent. S. P.: Holm. E.: Dick. H.: Mandrup, K. J. Radioand. Nucl. Chem. 1989. 131, 171 .

9. Meyer. R. J.: Oldham, R. D.: Larsen, R. P. Anal Chem. 1964. 36. 1975.

10. Franson. M. A. H. Standard 1 lethods for the Examination of Water and Wastewater. 20th ed.: Am. Pub. Health Assoc. Washingtonl. 1998: pp 4.55-4.56.

11. Kleykamp, H. J. Nicl Mater. 1985, 131. 221.

12. Seddon. E.: Seddon. K. The Chemistry of Ruthenim, Elsevier Sci. Pub: Amsterdam, 1984; pp 57-160.

13. Cady. H. H.: Connick. R. E. J. Am. Chem. Soc 1958. 80.2046.

14. Kolthofi. I. M.: Elving. P. T. Treatise on Anahtical Chentistry: Interscience Pub.: New York. 1964: Part II. Vol. 6. p 413. 